\title{
The Marketing Mix in a Marketing 3.0 Context
}

\author{
Dennis Warrink
}

\author{
University of Twente, Enschede, The Netherlands
}

\begin{abstract}
Modern society is becoming increasingly aware of the necessity to behave sustainably which resulted in higher expectations towards sustainable practices of businesses. Thus, Marketing 3.0, a concept developed by Kotler, Kartajaya, and Setiawan (2010) which takes a more sustainable approach towards marketing, received an increasing amount of attention in the academic and practical world. This paper, therefore, identified the various influences this new marketing era has on the widely known and accepted 7P Marketing Mix to provide a valuable literature basis for the effect of Marketing 3.0 on marketing practices in the form of an in-depth literature review. Furthermore, an evaluation of ethical issues regarding the new marketing era is presented $w$ ith the aim of receiving a comprehensive and critical overview of this new emerging topic. The use of Marketing 3.0 practices is expected to generate benefits for customers and companies simultaneously by creating a more sustainable and making the world a better place. The efficient use Marketing 3.0 also aims to result in higher consumer trust through the use of collaboration practices. Moreover, findings suggest that Marketing 3.0 highly impacts six out of the seven Marketing Mix Ps, namely product, price, promotion, process, people, and physical evidence, as well as mildly influences place. Therefore, the concept of Marketing 3.0 is a crucial extension of current marketing practices by providing economic profits, while at the same time taking into consideration environmental, ethical, and social factors.
\end{abstract}

Keywords: Marketing 3.0, Environmental value-driven marketing, Sustainable marketing, Ethical marketing, Green marketing, Marketing Mix, 7Ps

\section{Introduction}

\subsection{Relevance of Topic}

Since the concept of Marketing 3.0 was introduced by Kotler, Kartajaya, and Setiaw wn in 2010, the attention around the development of this marketing concept is increasingly growing and a rising amount of corporations see business opportunities in the emergence of Marketing 3.0 (Bridges \& Wilhelm, 2008; Kotler, Kartajaya, and Setiawan, 2010; Gupta \& Kim, 2010; Lee \& Kwak, 2012; McDonagh \& Prothero, 2014; Susilo, Yulius, \& Suryati, 2015). While the evolution of Marketing 3.0 influences various sectors, this paper will focus on its benefits and drawbacks in the economy sector (Kotler et al., 2010, Lee \& Kwak, 2012).

Research suggests that consumers are increasingly losing trust in traditional business practices, as a result of the financial crisis and environmental issues (Kotler et al., 2010; McDonagh \& Prothero, 2014). Additionally, improving technologies increased the communication among consumers, but also between consumers and companies radically in recent years (Katona, Zubcsek, \& Sarvary, 2011; Rahbar \& Wahid, 2011; Lee \& Kwak, 2012). Taking this into consideration, Kotleret al.'s (2010) argumentation, stating that the marketing concept of Marketing 3.0 solves the problem of diminishing consumer trust seems justifiable. This view finds a variety of supporters among researchers, who declare that a new marketing concept that focuses on the society as a whole is required (Rahbar \& Wahid 2011; Gupta \& Kim, 2012; Susilo et al., 2015). Although Marketing 3.0 is not going to compensate for traditional approaches, there is evidence that it provides a crucial enhancement of preexisting 


\section{Dennis Warrink \\ The Marketing Mix in a Marketing 3.0 Context}

marketing approaches (Kotler et al., 2010). Since branding and advertising are assumed to have a relevant impact on consumer preferences for products, it is likely that the Marketing 3.0 approach could contribute to establishing an environmental friendly, ethical, and likeable brand in a positive way (Kotleret al., 2010, Meffert, Rauch, \& Lepp, 2010; Susilo et al., 2015).

\subsection{Why Marketing 3.0 is Important}

The new Marketing 3.0 concept is of crucial importance for both companies and society, since it is presumed that there is potential to receive new, valuable insights by various groups of customers through different types of communication channels, which will affect the decision making process and give access to creative content not obtainable by former traditional marketing concepts (Kotler et al., 2010; Liu, Kasturiratne, Moizer, 2012; Malhotra, Lee, \& Uslay, 2012; Susilo et al., 2015). Also, it is assumed that this marketing concept takes a step further in "making the world a better place" (Kotler et al., 2010, p.4). Even though some authors raise critical claims because they fear that companies might only claim to engage into Marketing 3.0 activities while, in reality, they do not, it is expected that this marketing approach will result in higher consumer trust. Thus trust will eventually lead to improved marketing activities by taking into account individual preferences, desires and needs re garding brands and product offering, as well as consumer behaviour in general (Liu, Kasturiratne, \& Moizer, 2012; Kimmel, 2015). Consumers, therefore, have the benefit of receiving products that fulfill their personal and societal needs, wants, as well as desires (Kotler et al., 2010).

\subsection{Background}

It is conspicuous that the interest in Marketing 3.0 was rapidly growing in recent years (Kotler et al., 2010; Susilo, Yulius, \& Suryati, 2015). As Google Trends shows, there is an upwards sloping interest in Marketing 3.0. The corresponding slope can be viewed in figure 1 . It slowly emerged in 2009 and, with the release of Kotler et al.'s book "Marketing 3.0" quickly gained interest, and now, there is still a high interest in the topic of Marketing 3.0 (Google Trends, 2015). This is also supported by the fact that more and more firms engage in Marketing 3.0 activities (Gupta \& Kim, 2010). This rapid emergence can be traced back to the evolution of new wave technology, and the implementation of computers and the internet, which crucially changed the way information is collected, communication takes place and advertisement is organized (Goetzinger, Park, Lee, \& Widdows, 2007; Kotler et al., 2010; Rawat, Bhatia, Hegde, Bhat, \& Tewari, 2015). Furthermore, there a re several macro-economic developments which can justify the emergence of Marketing 3.0, like the movement away from a linear approach towards a circulareconomy, where biological nutrients re-enter the biosphere safely, and technical nutrients are designed to be re-used, repaired, or upgraded without entering the biosphere, which in returns decreases cost and improves the environment (Chen, 2009; Tukker, 2013; Liu \& Bai, 2014). Another factor is the emergence of environmental economics, which undertakes studies on the economic effects of global, national, or local environmental policies that deal with air pollution, water quality, solid waste, toxic substances, and global warming (Callan \& Thomas, 2007; Mäler, 2011). Therefore, Marketing 3.0 builds a new concept that deals with these economic developments.

\subsection{Situation}

Currently, the market is full of similar and standardized products and services, often causing high environmental damage through pollution, child labor, or likew ise actions (Cronin, Smith, Gleim, Ramirez, \& Martinez, 2010; Luchs, Naylor, Irwin, \& Raghunathan, 2010; Nisen, 2013). Modern technologies opened up new ways in which the society can raise claims and engage into business and governmental work, resulting in changing expectations on what and how companies produce and how they behave (Rahbar \& Wahid, 2011; Lee \& Kwak, 2012, Rettie, Burchell, \& Riley, 2012). Moreover, companies increasingly take into consideration what consumers demand in their products which makes innovative differentiation among products and services a crucial discipline to customize to meet their target groups' needs (Cronin et al., 2010; Malhotra et al., 2012). Acting upon customer needs and desires, thus, became of crucial 


\section{Dennis Warrink \\ The Marketing Mix in a Marketing 3.0 Context}

importance for a business' success (McDonagh \& Prothero, 2014; Kimmel, 2015). Nevertheless, factors like the financial crisis, the emerging globalization, child labor, and the climate change increasingly raises anxieties of the society in regards to business activities (Kotler et al., 2010; Luchs et al., 2010; Rettie et al., 2012). This resulted in an increasing amount of companies losing market share due to not doing business to what consumers consider to be environmental-friendly or spiritually correct (Nisen, 2013; Rawat et al., 2015). Therefore, an increasing amount of consumers request companies to engage in doing more environmental-friendly business and increase transparency, collaboration, and participation of consumers in order to diminish societal anxieties (Kotleret al., 2010; Chatterjee, 2011; Rahbar \& Wahid, 2012, Lee \& Kwak, 2012; Rawat etal., 2015). This builds the new foundation of what Kotler et al. (2010) refer to as Marketing 3.0.

\subsection{Definition of Marketing 3.0}

In order to define what Marketing 3.0 is, it is important to examine the degree to which marketing changed within the last few years. Traditionally, the term 'marketing' was defined as a management process which was responsible for identifying, anticipating, as well as satisfying customer requirements in a profitable way (Adcock, Halborg, Ross, \& Financial Times Limited, 2001; CIM, 2009). This definition represents, according to Dann (2009), a more disciplined marketing management view of discipline, in which profitability is the key focus. With the introduction and emergence of information technologies which empowered customers, marketers increasingly criticized this definition by stating the value of the customers in the marketing processes. Thus, researchers started to form a new definition for the term 'marketing', which was more consumer-oriented and took into account that marketing is a social and societal process, where the satisfaction and retaining of customers is key in order to form one-to-one relationships with customers (French \& Blair-Stevens, 2006; Kotler \& Lee, 2008, Dann 2009). In 2008, the American Marketing Association (2008) launched a new definition of the term 'marketing.' It was now defined as "the activity, set of institutions, and processes for creating, communicating, delivering, and exchanging offerings that have value for consumers, clients, partners, and society at large" (AMA, 2008). This definition built the foundation of the emergence of Kotler et al.'s (2010) introduction of the term 'Marketing 3.0'.

According to Kotler et al. (2010), this definition by the AMA (2008) was the first definition, which realized that marketing actually had the capability of adding value to society by recognizing the large-scale impacts beyond what happens in the private dealings of individuals and companies (Kotler et al., 2010). Additionally, this new definition showed that marketing is ready to address cultural implications which resulted by the formation of globalization, resulting from the grow th of new wave information and transportation technologies (Meffert, Rauch, \& Lepp, 2010; Rettie et al., 2012). Even though Kotler et al. (2010) does not provide one clear definition of what Marketing 3.0 is, they state that it is the emergence of the valuesdriven era where customers are regarded as whole humans with minds, hearts, and spirits. Therefore, Marketing 3.0 is the activity and process for creating, communicating, delivering, and exchanging product offerings that have value for consumers, clients, partners, and society at large, by resolving humans'anxieties and performing at the societies'functional, emotional, as well as spiritual level. (AMA, 2008, Kotler et al., 2010). Furthermore, literature states that Marketing 3.0 now has large-scale impacts beyond private dealings of individuals and companies and that it is ready to address the cultural implications of globalization. (Rettie et al., 2012; Liu et al., 2012). The specific contents and principles for Marketing 3.0 will be further specified and analyzed throughout this paper.

\subsection{Goal of Study}

The present paper aims at introducing the reader to the topic of Marketing 3.0 and how companies and consumers can use it efficiently. Since the references on this topic are very numerous, and results from various researchers encompass a variety of different opinions, this 


\section{Dennis Warrink \\ The Marketing Mix in a Marketing 3.0 Context}

paper provides the reader with an objective and comprehensive analysis of different scientific literature. However, the majorgoal of this paper is to evaluate upon the influence of Marketing 3.0 on the 7P Marketing Mix: Product, place, price, promotion, process, people, and physical evidence. Therefore, the goal is to assess in which way these marketing inputs are influenced by the emergence of Marketing 3.0 and what this means for marketers.

Generally speaking, it is expected that a company that efficiently implements Marketing 3.0 techniques does not only attract and retain a loyal customer basis, but also helps to make the world a better place (Cronin, Smith, Gleim, Ramirez, \& Martinez, 2010; Kotler et al., 2010; Rettie et al., 2012; Erragcha \& Romdhane, 2014). Furthermore, developing a sustaining brand by solving consumers' anxieties is hoped-for (Kotler et al., 2010; Meffert et al., 2010; Erragcha \& Romdhane, 2014). Additionally, Marketing 3.0 aims at saving money in the long run and increasing efficiency by listening to the customers' voice rather than forcing product offerings on them (Kotler et al., 2010; Susilo et al., 2015). In this literature review, the main focus lies on the accumulation and evaluation of relevant literature concerning the influence of Marketing 3.0 on the key marketing inputs mentioned above.

\section{Academic Relevance}

This paper mainly focusses on the cross-linkage between the widely known 7P Marketing Mix and the influence of Marketing 3.0 on these factors. Therefore, a first-of-its-kind evaluation on linking the concept of Marketing 3.0 to the 7P Marketing Mix model is provided. Hence, this paper is expected to provide a valuable basis in the literature field of Marketing 3.0 since there is currently no literature that reflects upon all these factors, providing an in-depth analysis on the abovementioned topic while also critically reflecting upon potential issues regarding the emergence of Marketing 3.0 within one paper.

\section{Practical Relevance}

Having a look at the impacts on the practical environment, it is expected that this paper provides a variety of detailed information on how the era of Marketing 3.0 changes the way companies should behave in regard to producing, pricing, promoting, placing, processing the product offering, as well as how to engage with important stakeholders. If done efficiently, this can help a company to form a long-lasting, relevant brand with an engaged customer base, while at the same time making the world a better place. On the other hand, one could argue that companies could start developing marketing strategies according to the principle of Marketing 3.0, advertising products that appear to help make the world a better place, while in reality, these products do not create any value for the environment. This would then, according to Liu et al. (2012), result in even further loss of trust in the business practices by consumers and eventually harm the business drastically in the long run.

Following this introduction and argumentation on the topic of Marketing 3.0, the following research problem arises: What is the potential impact of the Marketing 3.0 concept on Marketing Practice?

\section{Research Questions:}

- What is Marketing 3.0 in regard to its core objective, enabling factors, how companies see the market, its key marketing concepts, and corporate marketing guidelines?

- What is the effect of Marketing 3.0 on the different factors of the 7P Marketing Mix, namely (1)product, (2)place, (3)price, (4)promotion, (5)process, (6)people, and (7)physical evidence?

- What are the issues that arise with the development of Marketing 3.0?

The paperwill be structured as follows. In the literature review part, all concerns regarding Marketing 3.0 and its importance as a marketing input will be explained, analyzing its 


\section{Dennis Warrink \\ The Marketing Mix in a Marketing 3.0 Context}

objective, its enabling factors, how companies see the market, its key marketing concepts and key marketing guidelines. Thereafter, a critical evaluation of the accompanying consequences on the Marketing Mix will be formulated, structured into seven prevalent factors: product, place, price, promotion, process, people, and physical evidence. After that, this paper will identify potential issues that arise with the emergence of Marketing 3.0 and will close with an overall evaluation by presenting a clear overview of the findings.

\section{Methodology}

This paper systematically and critically analyses relevant scientific literature regarding the subject of Marketing 3.0, its overall objective, enabling forces, and key concepts and guidelines in order to identify Marketing 3.0's influence on the 7P marketing mix. The method of this paper is a literature review, as it compresses the key findings of various research in this area, as well as combines previously discovered research findings, and critically reviews these. A distinction between quantitative and qualitative research, or between professional and academic literature was found to be unnecessary.

While offline library provided useful literature for the present paper, an essential part of relevant information and data has been collected by making use of electronic search engines like Scopus, Google Scholar, Science Direct, and the University of Twente online library. After receiving the literature provided by the electronic search engines, it had to be decided on whether an article was relevant or not. This was done by scanning the abstract, the year of publication, and the journal in which the article was published, followed by an examination of the introduction and conclusion, followed by an in-depth inspection of the entire article. When literature was found to be relevant, its content was then analyzed and included into a literature matrix in order to have a structured and comprehensive overview over the content of the respective references (see Figure 1,Appendix). The literature matrix listed the author and year of publication in the first column downwards, and the (sub-) topics in which this paper is divided in in the top row. The relevant information of the several literatures was then written into the remaining columns which gave a structured and clear sketch of what which reference said concerning what (sub-) section of this paper. Additionally, the reference lists of the most relevant articles were additionally scanned in order to find further articles for the present literature review. Overall, 86 pertinent scientific references were found, consisting of scientific books, as well as scientific articles and journals, accompanied by four admissible online websites.

When searching for relevant references, several key search terms were used. Primarily, the term 'marketing 3.0' was used, but also 'social media', 'marketing', 'social media marketing', 'online marketing', 'environmental value driven marketing', 'ethical marketing', 'online consumer integration marketing', as well as 'sustainability marketing' and 'green marketing'. In this context, it should be stated that entering the search term 'marketing 3.0' in Google Scholar resulted in 276,000 hits. Furthermore, the online library of the University of Twente yielded 266 results using the same search term, while the search engine Scopus led to 231 results.

A source that is frequently discussed in this paper is the book "Marketing 3.0: From products to customers to the human spirit" by Kotler, Kartajaya, and Setiawan. The book was released in May 2010 and discusses the shift from satisfying and retaining individual consumers and addressing their needs towards environment-valued marketing of making the world a better place by resolving consumers' anxieties and intertwined values (Kotler et al., 2010).

Moreover, the book 'Basic Marketing: a managerial approach" by McCarthy which was released in 1964 is another relevant source used in this paper since it introduced the basic $4 \mathrm{P}$ - product, price, place, promotion - Marketing Mix model. 


\section{Dennis Warrink \\ The Marketing Mix in a Marketing 3.0 Context}

Furthermore, the article "Marketing Strategies and Organization: Structure for Service Firms" (1981) by Bitner and Booms and "Introduction to marketing: Theory and practice" (2012) by Palmer is referred to. Bitner and Booms (1981) enhances the 4P approach introduced by McCarthy (1964), stating that it focuses too much on products. Therefore, in order to make the model suitable for service, they enhanced the 4P model by adding three more Ps, Process, People, and Physical Evidence (Bitner \& Boom, 1981; Palmer, 2012). Palmer (2012) additionally views the 7P context in a more modern context.

The references used for this paper often use contradicting arguments which is why this paper critically evaluates the content of the respective literature. This ensures strong, valid, and convincing reasoning.

\section{The Emergence of Marketing 3.0}

In this section, the principle of Marketing 3.0 will be examined, reflecting on Kotler et al.'s (2010) book. Also, it will be identified what other literature, which discusses the topic of marketing that aims at making the world a better place have to add to or criticize Kotler et al.'s (2010) view. This section will reflect on the overall objective of Marketing 3.0, its enabling factors, and discuss how companies now see the market now. Then, the key marketing concepts will be introduced, as well as the key marketing guidelines

\subsection{Objective}

The way marketing is viewed changed with the introduction of Marketing 3.0 (Kotler et al., 2010; Kotler, 2011 ; L.C. Leonidou, C.N. Leonidou, Fotiadis, \& Zeriti, 2013). Marketing 2.0 was regarded as consumer-oriented marketing which aimed at satisfying and retaining consumers (Kotler et al., 2010). On the other hand, Marketing 3.0 assimilates a more holistic approach on marketing (Kotler, 2011; Susilo, Yulius, \& Suryati, 2015). Its main objective is therefore to make the world a better place (Kotler et al., 2010). Kotler et al. (2010) clearly state that Marketing 3.0 can be regarded as an enhancement of Marketing 1.0 and 2.0, which means that the objective of selling products in Marketing 1.0, as well as the consumer-oriented approach of Marketing 2.0 build the foundation of Marketing 3.0. Nevertheless, Marketing 3.0 has higher aims than simply creating individual values. Rather, it aims at gaining environmental and societal value by supplying meaning as the future value proposition in marketing (Kotler et al., 2010). It acts on recent findings that psycho-spiritual benefits are the most essential need of consumers and therefore might represent a crucial, effective differentiation and competitive advantage a company can establish (Leonidou et al., 2013; Erragcha \& Romdhane, 2014). Marketing achieves this object by implementing marketing on a spiritual level (Kotler et al., 2010). In order to do this efficiently, companies need to define what is meant by spirituality. We define spirituality as valuating nonmaterial attitudes of life and intimation of an enduring reality (Handy, 1998). Referring this definition on business actions, it means that Marketing 3.0 takes consideration of the triple bottom line (Cronin et al., 2010). The triple bottom line implies that a business simultaneously and equally needs to consider environmental, social, as well as economic factors when doing business (Cronin et al., 2010). While research mainly shares Kotler et al.'s (2010) opinion that the main goal of this marketing era is about making the world a better place, research add several factors to this concept (Liu et al., 2012; Luchs et al., 2010; Ansar, 2013; Ndubisi, Nataraajan, \& Lai, 2013; Rawat, Bhatia, Hegde, Bhat, \& Tewari, 2015). For instance, Ndubisi et al. (2013) state that ethical marketing, the concept of honesty and ethically right behaviour towards society is an important marketing tool in order to reach the aims of Marketing 3.0. On the other hand, other researchers suggest that the concept of sustainability marketing or green marketing which focuses on the use of environmental and societal friendly products in the production of services and products are the key for reaching the goals of Marketing 3.0 (Iles, 2008; Cronin et al., 2010; McDonagh \& Prothero, 2014). 


\section{Dennis Warrink \\ The Marketing Mix in a Marketing 3.0 Context}

Additionally, it should be stated that nearly all of these references share the opinion that cocreation with various stakeholders, especially consumers, is a crucial part of this marketing era (Kotler et al., 2010; Malhotra et al., 2012; Erragcha \& Romdhane, 2014; Kimmel, 2015; Susilo et al., 2015). Since all these concepts share the same overall goal, they will all be taken into consideration for the further assessment of this paper in order to come up with a comprehensive and critical analysis of what this new emerging marketing era entails.

\subsection{Model Specification}

References identified three main factors responsible for the shift from Marketing 2.0 to Marketing 3.0 are the rise of new wave technologies, globalization, as well as the age of creative society (Kotler et al., 2010; Gupta \& Kim, 2010).

\subsubsection{New wave technologies}

Kotler et al. (2010), as well as Gupta \& Kim (2010) state that new wave technologies are the driving forces that are responsible for creating a more value-driven marketing approach, resulting in the emergence of Marketing 3.0. Additionally, other researchers came to the conclusion that these new wave technologies resulted in the emergence of a more ethical and environmental-friendly approach (Rahbar \& Wahid, 2011; Liu et al., 2012). New Wave Technologies are defined as technologies that facilitates the interactivity and connectivity of groups and individuals (Kotler et al., 2010). Therefore, literature identifies the emergence of social media as a new wave technology that was relevant for the emergence of Marketing 3.0. (Kotler et al., 2010; Kaplan \& Haenlein, 2010; Hettler, 2010; Lee \& Kwak, 2012). The term Social Media refers to an online platform where users can create, modify, share, and discuss internet content (Boyd \& Ellison, 2007; Kaplan \& Haenlein, 2010; Hettler, 2010; Kietzmann, Hermkens, McCarthy, \& Silvestre, 2011; Chatterjee, 2011). The two types are expressive social media and collaborative social media (Kotler et al., 2010). Expressive social media like Facebook, YouTube, and blogs enables its users to communicate by sharing text, picture, video, and music with others (Kotler et al., 2010; Lee \& Kwak, 2012). The use of expressive social media has been increasing tremendously in the past few years. For instance, NM tracked more than 181 million blogs around the world by the end of 2011, while they just tracked around 36 million only five years earlier in 2006. (Nielsen, 2012). Also, between 2008 and 2009 the number of Twitter accounts increased by $1,298 \%$ in only one year. (Kotler et al., 2010). Therefore it is not surprising that companies increasingly realize the importance of expressive social media, resulting in more and more companies engaging actively on Twitter, Facebook, or other social media sites (Kotler et al., 2010; Hettler, 2010). On the other hand, collaborative social media like Wikipedia, Rotten Tomatoes, and InnoCentive aims at facilitating to achieve common goals for society by communicating, working together, and engaging in social processes (Kotler et al., 2010; Lee \& Kwak, 2012; Lee \& Kotler, 2011). In recent years, collaborate social media has been more and more growing (Kaplan \& Haenlein, 2010). For instance, in January 2014, Wikipedia offered more than 4,413,000 English articles, while in January 2004 only 188,800 English articles were available, indicating that the number of English Wikipedia articles increased by more than $23000 \%$ in only 10 years (Wikipedia, 2015).

\subsubsection{The age of Globalization paradox}

The rise in communication and transportation technologies further resulted in the emergence of globalization (Kotler et al., 2010; Cronin et al., 2010). While the rise of communication technologies enabled the exchange of intangible resources like information and knowledge, developments in transportation technologies enabled the exchange of tangible resources like goods and workforce among nations, companies, and individuals on a global scale (Cronin et al., 2010). Globalization can be defined as the "widening, deepening and speeding up of worldwide interconnectedness in all aspects of contemporary life, from the cultural to the criminal, the financial to the spiritual (Held, McGrew, \& Goldblatt, 1999; Armstrong, Adam, Denize, \& Kotler, 2014). Therefore, globalization creates an interlinked economy, since it effects everyone around the world and influences culture in various ways (Kotler et al., 2010). 


\section{Dennis Warrink \\ The Marketing Mix in a Marketing 3.0 Context}

Nevertheless, unlike technologies, globalization inherits paradoxes. One paradox is, that globalization literates, while simultaneously putting pressure on nations and people globally. (Kotler et al., 2010; Erragcha \& Romdhane, 2014). Next to that, globalization is calling for economic integration but is not creating equal economies, creating both globalism a nd tribalism (Stiglitz, 2002; Kotler et al., 2010). Globalism refers to the creation of one universal culture emerging through the exchange of tangible and intangible resources and communication among borders (Kotler et al., 2010). On the other hand, tribalism is the concept of strengthening local culture due to tradition, local community, or geographical factors (Kotler et al., 2010). These factors result in individuals feeling pressure to become local citizens as well as retaining their local citizenship. Therefore, paradoxes like the two mentioned above result in anxiety and intertwined values in persons' minds (Kotler et al., 2010; Erragcha \& Romdhane, 2014). Evidently, these two paradoxes are not the only paradoxes that are important for the rise of Marketing 3.0, but they are the two most prominent ones (Kotler et al., 2010).

\subsubsection{The age of creative society}

Next to globalization, the rise of a creative society, enabled by improved technology has been identified as a major driver for the emergence of the new marketing era (Kotler et al., 2010; Erragcha \& Romdhane, 2014; Kimmel, 2015). The number of creative people within society seems to be comparatively small, but their role is crucial, since they create and use new concepts, as well as new technologies (Kotler et al., 2010). Pink (2005) states that this type of society represents the highest level of social development in human civilization. They make the most collaborative and expressive use of social media and have a high influence on the society with their way of life and attitudes, and they tend to shape opinions of others (Chatterjee, 2011; Sweeney, 2014). They are the hubs that connect consumers (Kotler et al., 2010). Florida (2005) investigated that there has been a recent increase in the creativity index in both the US and Europe. This index measures the degree of creative development of a nation based on enhancement of technology, talent, and tolerance (Florida, 2005). Already 25 years ago, it was stated that creativity is what makes human beings different from other creatures, and that creative people always seek to improve themselves or the world (Zohar, 1990; Malhotra, Lee, \& Uslay, 2012). Creativity expresses itself in terms of morality, humanity, as well as spirituality (Zohar, 1990). For marketers, it is important to realize that creative society favor cultural and collaborative brands and that they tend to criticize brands with a negative triple bottom line (Cronin et al., 2010; Kotler et al., 2010; Malhotra et al., 2012; Kimmel, 2015). Moreover, the creative society seeks beyond what money can buy, namely meaning, happiness, and spiritual realization (Kotler et al., 2010).

\subsection{Companies' perception of the market}

Over the past few decades, the way companies see the market has evolved through various stages (Kotler et al., 2010; Rahbar \& Wahid, 2011). During the phase of Marketing 1.0, companies solely saw the market as consisting of mass buyers with physical needs (Ries \& Trout, 1989; Kotleret al., 2010; Erragcha \& Romdhane, 2014). For marketing, this meant that the consumers' minds had to be addressed uniquely and meaningfully when the idea of a product is positioned in the market (Ries \& Trout, 1989; Malhotra et al., 2012). Lateron, when consumers got increasingly empowered by information technologies, companies realized that tackling the consumers' mind is not enough anymore (Erragcha \& Romdhane, 2014). Companies started to see consumers as human beings whose mind, as well as emotional heart had to be targeted through marketing (Kotler et al., 2010). This was done through emotional marketing, which aims at targeting actual and potential customers' hearts, which carry emotions and feelings (Kotler et al., 2010; Malhotra et al., 2012). Nevertheless, as many researchers identified, the market in which businesses operate is increasingly shifting towards a low-trust environment where consumers, in general, have lost their faith in the practices conducted by businesses (Rahbar \& Wahid 2011; Chatterjee, 2011; Erragcha \& Romdhane, 2014). 


\section{Dennis Warrink \\ The Marketing Mix in a Marketing 3.0 Context}

As research claims, marketing is partly responsible for this, because companies tend to exaggerate about differentiation and product performance with the aim of increasing sales (Erragcha \& Romdhane, 2014). To tackle this issue, Kotler et al. (2010) realized that consumers need to be addressed as whole human beings according to Covey's (2005) definition, which sees a whole human being as being composed of four basic components: a physical body, a mind able to have independent thoughts and analyses, a heart capable of feeling emotions and a spirit, the soul or philosophical centre. While the first three components were already addressed by marketers, they increa singly realize that the consumers' spirits, so their deepest anxieties and desires, have to be targeted as well if the company wants to stay relevant in the market (Convey, 2005; Kotler et al., 2010; Erragcha \& Romdhane, 2014). Therefore, it can be stated that in Marketing 3.0, the market is regarded as consisting of whole human beings with a rational mind, an emotional heart, and a philosophical spirit (Kotler et al., 2010; Malhotra et al., 2012; Erragcha \& Romdhane, 2014). Further research on this topic suggests that the society often does not know which factors have a significant impact on their spiritual fulfillment (Iles, 2008; Liu et al., 2012; McDonagh \& Prothero, 2014). Therefore, they suggest that companies should also see the market as people who need to be educated about the factors that enables the society to achieve spiritual fulfillment and what consumers can do in order to participate in the process of making the world a better place (Rahbar \& Wahid 2011; Liu et al., 2012; McDonagh \& Prothero, 2014).

\subsection{Key Marketing Concepts}

The new emerged concept of Marketing 3.0 faces new building blocks in order to solve the emerging anxieties and problems that aroused through the emergence of new wave technology, globalization, and the rise of a more creative society (Kotleret al., 2010). To solve these Kotler et al. (2010) formulated three Marketing 3.0 building blocks that form a suitable solution to these problems. First, to handle the increasing amount of consumer participation through the emergence of new wave technology, companies are advised to deal with this through the concept of collaborative Marketing (Kotler et al., 2010). Collaborative marketing implies that companies align their interests, resources, and marketing activities with other like-minded stakeholders, like consumers and other companies, in order to accomplish more than it might have been able to do on its own (Williams, 2013; Chen, K.J., Chen, M.L., Liu, \& Huang, 2015). The concept of collaborative marketing therefore stimulates the desire of consumers to interact with the brand and other consumers in order to be more involved into marketing activities by forming creative content themselves (Kotler et al., 2010; Berthon, Pitt, Plangger, \& Shapiro, 2012).

Secondly, Kotleretal. (2010) propose the concept of cultural marketing to deal with the arising globalization paradoxes that were introduced in the last section, especially the arising of tribalism and globalism. Cultural marketing, therefore, seeks to get behind the movements and trends within a prevailing culture (Klepic, 2014). So cultural marketing aims at solving the problems that arose through the globalization which it does by giving context to marketing activities (Kotler et al., 2010).

Lastly, spiritual marketing was introduced as a new emerging trend in Marketing 3.0 (Kotler et al., 2010). The concept of spiritual marketing has gained relevance because it is said to be tackling the age of creativity and forms an opportunity for this trend (Kotler et al., 2010; Erragcha \& Romdhane, 2014). According to Kotler et al., (2010), spiritual marketing activities have the goal of not only satisfy consumer needs but touch their spirit and supply individual and societal meaning to marketing activities (Kotler et al., 2010).

\subsection{Key Marketing Guidelines}

In order to be able to gain the most benefits of the current market situation under 3.0, marketing needs to be redefined. Kotler et al. (2010) propose this in form of a consonant triangle, which can be seen in Figure 2. The purpose of the brand triangle is, that, according 


\section{Dennis Warrink \\ The Marketing Mix in a Marketing 3.0 Context}

to Kotleret al. (2010) even though a brand may already have an identity in consumers' heads, it does not necessarily have to be a good one, and that firms need to be aware of that. It works as a reminder for businesses to be authentic since consumers tend to quickly make up their mind whether a brand is authentic or not (Kotler et al., 2010). The differentiation triangle is regarded to represent the brand's DNA which mirrors the brand's true identity and acts as a solid proof that a brand delivers what it promises (Kotler et al., 2010; Chen et al., 2015).

Brand identity refers to the claim of positioning the brand in the mind of consumers by being unique, as well as being relevant to consumers' rational needs and wants (Kotler et al., 2010). Kotler et al. (2010) further state that brand image is concerned with the acquisition of a strong share of consumers' emotions. Therefore, it appeals to emotional needs and wants beyond functionalities \& features, representing Marketing 2.0 factors (Kotler et al., 2010). Brand integrity, on the other hand, refers to the requirement of actually fulfilling what is claimed through the positioning and differentiation of the brand. This has to be done by being and remaining credible, fulfilling promises, and establish consumers' trust (Delmas \& Burbano, 2011). Therefore, brand integrity is what comes new in the era of Marketing 3.0, since it targets the spirits of the customer. (Kotler et al., 2010; Erragcha \& Romdhane, 2014).

The model by Kotler et al. (2010) therefore shows, how interdependent the mind, emotional and spirit values are for marketing and that Marketing 1.0 and 2.0 factors are still relevant nowadays in the era of Marketing 3.0 (Kotler et al., 2010; Malhotra et al., 2012; Erragcha \& Romdhane, 2014). Literature adds that the best approach to include good deeds in the corporate culture and maintain commitment is by embedding them into the company's mission, vision, and values (Kotler et al., 2010). This point is shared by Drucker (2006), who further states that successful businesses with the performance of their mission and not with planning financial returns, and that if done right, financial returns will eventually come as a result. Furthermore, it is stated that a company should characterize its mission as fundamentally as possible so that it will determine the sustainability of the company (Kotler et al., 2010). It also needs to explain what the company aspires to become and achieve (Malhotra et al., 2012).

Literature reveals that a consonant brand-positioning differentiation is the main success factor in the era of consumer empowerment through social media, since there is no chance that inauthentic companies survive in the time of consumer empowerment and electronic word of mouth (Conelly et al., 2010; Kotler et al., 2010; Lee \& Kotler, 2011; Park \& Kim, 2014). It also implies that companies are advised to reduce the amount of vertical communication and engage into a more horizontal form of communication with consumers (Malhotra et al., 2012; Kimmel, 2015; Susilo et al., 2015).

\section{Theoretical Framework}

In order to theoretically test the effect of the most recent Marketing 3.0 developments on the 7P Marketing Mix, this paper presents a new model, due to the absence of applicable theoretical models in the currently accessible literature.

As it is shown in figure 3 (see appendix), the theoretical framework "Marketing 3.0's potential influence on the 7P marketing mix" hypothesis that Marketing 3.0 has an influence on the marketing mix model's (1)product, (2)place, (3)price, (4)promotion, (5)process, (6)people, (7)physical evidence. Furthermore, it will be evaluated in how far the perception of the different 7Ps has changed between Marketing 2.0 and Marketing 3.0. After the hypotheses have been tested, will be discussed and can be seen in table 2 and table 3 . 


\section{Marketing 3.0's Effect on the 7p Marketing Mix Model}

Since traditional marketing techniques are no longer able to completely grasp modern markets, the implementation of Marketing 3.0 is expected to result in an improved marketing strategy, which not only enables long-term financial performance, but also environmental improvements (Kotler et al,., 2010; Luchs et al., 2010; Liu et al., 2012; Malhotra et al., 2012). Thus, the effect of the implementation of the Marketing 3.0 concept on the widely known 7P Marketing Mix will be evaluated in more detail.

\subsection{Product}

Research states that companies are increasingly getting the customer involved in the creation and development of new products (Kotler et al., 2010; Liu et al., 2012; Malhotra et al., 2012). This new form of co-creation creates new product and experiences through collaboration by companies with their consumers, but also their suppliers and further stakeholders (Kotler et al., 2010; Liu et al., 2012). This implies that companies, consumers, channel partners, and suppliers are jointly involved in creating product and experience through collaboration in a network of innovation (Kotler et al., 2010; Malhotra et al., 2012). An increasing amount of companies use their online presence and other media to engage consumers into the creation of new products and services (Gupta \& Kim, 2010; Rahbar \& Wahid, 2011; Liu et al., 2012). Companies can learn from consumers since consumers often use a certain product differently as it was intended by the company, resulting in personalised experiences which create value for the company and the consumer, leading to a win-win situation for both parties (Cronin et al., 2010; Kotleret al., 2010; Malhotra et al., 2012). Kotler et al. (2010) even created a threestep process in order to generate co-creation. First, a "platform" should be developed by the company that represents a generic product that can be customised further. Next, individual consumers within the network get the ability to customise the platform according to their unique identities. Lastly, the company is advised to ask consumers for feedback and enhance the generic product platform by unifying the customisation efforts made by consumers (Kotler et al., 2010). While in Marketing 2.0 individual product needs and wants where the aim of marketers, Marketing 3.0 has a higher aim of resolving anxieties of the society (Kotler et al., 2010). This is why in the era of Marketing 3.0, consumers are increasingly requesting products that do not harm the environment. This is why more and more companies try to resolve consumer anxieties by implementing more environmental-friendly products (Malhotra et al., 2012; Thring, 2013). For instance, McDonald's increasingly includes healthier food options into their offerings in order to counteract on the increasing obesity a mong society and the resulting pressure for healthier food options among fast-food chains (Thring, 2013). Moreover, clothing companies like H\&M and Target released clothing lines which uses more environmental-friendly ingredients, e.g. bio-cotton (Dishman, 2014). Nevertheless, there are also more critical opinions on the implementation of environmental-friendly products or ingredients into the range of product offerings. Researchers like Meffert et al. (2010) state that they found out that many consumers do not view environmental-friendly products as a basic need, but more as an added benefit, not realizing the importance of using more environmental-friendly product options. Therefore, it can be concluded that the Marketing 3.0 era creates a shift regarding products towards co-creation with consumers and other stakeholders. Additionally, consumers increasingly request sustainable products.

\subsection{Place}

Currently, there is a lack of literature available that examines the direct impact of Marketing 3.0 practices on the place building block of the Marketing Mix. Nevertheless, current trends will be evaluated which should be taken into a ccount in order to investigate the potential effect of Marketing 3.0 on the place. In regards to place, research reveals that consumers want information fast and whenever they want it (Goetzinger et al., 2007; Armstrong et al., 2014). Resulting from this, a company that is, for instance, selling healthy food can benefit from an 


\section{Dennis Warrink \\ The Marketing Mix in a Marketing 3.0 Context}

online store in a way that once a person searches for information related to th is topic, he can directly purchase the product online. Additionally, due to recent technology developments like the Internet of Things and the Web 3.0, it is expected that there will be a further shift towards online selling, since people can access the internet whenever they are, at any time they want (Fuchs, Hofkirchner, Schafranek, Raffl, Sandoval, \& Bichler; 2010; Gubbi, Buyya, Marusic, \& Palaniswami, 2013). Therefore, it is expected that upcoming technological developments will result in a further shift towards online selling due to improving technology.

\subsection{Price}

During the era of Marketing 2.0, information technology eased the comparison of prices for a product among several retailers (Gupta \& Kim, 2010). Nevertheless, as researchers investigated, this does not mean that the cheapest product is the most successful one (Gupta \& Kim, 2010; Ansar, 2013). Nowadays, consumers are increasingly willing to pay a price premium for reputable vendors (Gupta \& Kim, 2010). This is related to previous positive experiences of a customer with a company, either by the buyer himself or other consumers in his community (Bell, 2011; Malhotra et al., 2012). With the emergence of Marketing 3.0, researchers increasingly detect an upward trend in the willingness of consumers to pay premium prices for environmental-friendly products and services, since these seem to tackle the societal anxieties Marketing 3.0 aims to diminish (Malhotra et al., 2012; Ansar, 2013). Ansar (2013) further investigated this, concluding that ecologica lly conscious consumers are significantly proven to be willing to pay premium prices for environmental-friendly, i.e. green products. Furthermore, consumers are more willing to pay premium prices to companies which are known for engaging in more sustainable business processes (Park \& Kim, 2014). Nevertheless, some research also states that high ethical standards in business can be achieved by maintaining high prices only if the associated costs are clearly identifiable (Ndubisi et al., 2013). Furthermore, research indicates that in some industries, consumers are less likely to pay premium prices for environmental-friendly products since they do not view these to be adding value to the product experience (Meffert et al., 2010; Sharma \& Iyer, 2012). Nevertheless, the implementation of Marketing 3.0 practices will eventually result in compensation for these current high prices (Kotler et al., 2010; Liu et al., 2012; Nyilasy, Gangadharbatla, \& Paladino, 2014). As research identified, reduces waste through more sustainable processes will eventually lead to fewer costs, which might result in lower prices (Cronin et al., 2010; Reisch \& Thøgersen, 2015). Furthermore, there is research that claims that governments should provide companies who engage into environmental business with subsidies, to make the engagement into sustainable business practices even more attractive for companies (Liu et al., 2012; Reisch \& Thøgersen, 2015). Concluding, it can be argued that Marketing 3.0 practices will eventually lead into lower prices for currently high priced sustainable products, so that there will be a higher range of people who can afford these and thereby help to create environmental and societal value.

\subsection{Promotion}

Regarding promotion, with the emergence of Marketing 3.0, Kotler et al. (2010) introduced the concept of 'communitisation'. The underlying principle of communitisation lies in the fact that consumers want to be connected to other consumers, not only to companies (Godin, 2008, Erragcha \& Romdhane, 2014). Kotler et al. (2010) therefore advises companies to facilitate this and comply the desire to connect to one another within communities. This is further coincide with Godin's (2008) view that the support of communities is a key factor for succeeding in business. Therefore, since consumers are becoming increasingly empowered, companies are advised to shift the communication from a vertical into a horizontal form of communication in which consumers engage in the creation of promotional activities, since consumers trust towards professional promotional activities is continuously decreasing (Kotler et al., 2010; Achrol \& Kotler, 2012; Liu et al., 2012; Kimmel, 2015; Susilo et al., 2015). Companies therefore increasingly invite consumers to create promotional content for the company (Kimmel, 2015). Malhotra et al. (2012) additionally stated that not only consumers, 


\section{Dennis Warrink \\ The Marketing Mix in a Marketing 3.0 Context}

but also employees and other stakeholders can efficiently contribute creative promotional content. Through the emergence of Social Media, companies can now easily enable consumers to connect into communities while obtaining potential ideas for several business activities through communications among customers, but also between customers and companies (Kotler, 2011; Achrol \& Kotler, 2011; Park \& Kim, 2014; Kimmel, 2015; Susilo et al., 2015). This is why in 2014 , more than $74 \%$ of Fortune 100 companies currently have Facebook brand pages, of which are more than $94 \%$ updated at least weekly (Park \& Kim, 2014). Nevertheless, research also suggests that Marketing 3.0 additionally aims at making the world a better place (Kotler et al., 2010).

Additionally, companies increasingly use promotional activities to not only sell products, but also to educate the listener about the sustainable services and products in order to encourage them to adopt susta inable behaviours and educate them on ways to decrease societal anxieties (Iles, 2008; Luchs et al., 2010: Rahbar \& Wahid, 2011; Ansar, 2013; McDonagh \& Prothero, 2014). This results from the fact that there is an information asymmetry between the society and business practitioners (Iles, 2008). On the other hand, there are researchers who state that this type of educational advertisement is unnecessary, since the society already knows what sustainable behavior consists of (Meffert et al., 2010; Rettie et al., 2012). Nevertheless, the creative modern society appears to have a critical view on ethical and sustainable marketing activities of companies, but once a company proves to be reliable in their actions, these consumers become very loyal to the corresponding company (Rahbar \& Wahid, 2011; Ndubisi et al., 2013; Susilo et al., 2015). One way to tackle the skeptical society is therefore to find creative influencers of the society and involve these in promoting sustainable activities and products in order to efficiently create positive word of mouth (Kotler et al., 2010). Malhotra et al. (2012) further states that companies need to leverage creative people and new technologies to generate positive word-of-mouth by, for instance, by setting up relationship marketing websites as an environment generated by the company that invites consumers to engage with the company, as well as other users. Taking this into account, it is not surprising that many companies like Volvic, Alverde, Starbucks and McDonalds started promoting sustainability in their promotional activities (Trefis, 2009; Meffert at el., 2010). Hence, promotional activities in Marketing 3.0 aims at creating joined efforts among various stakeholders, through horizontal communication, in order to create sustainable win-win situations by reliably promoting sustainable behavior, products, and services, thereby making the world a better place (Kotler et al., 2010; Malhotra et al., 2012). Additionally, companies increasingly use promotional activities in order to educate consumers about the necessity of sustainable products.

\subsection{Process}

In order for Marketing 3.0 to be efficient, all the different building blocks of the 7P marketing mix must work together (Meffert et al., 2010). Therefore, companies are in the need for greater integration between marketing and their other activities, especially their supply chain in order to ensure that sustainable supply chains reduce environmental and social adverse effects (Cronin et al., 2010; Liu et al., 2012; Brindley \& Oxborrow, 2013; Susilo et al., 2015). Conelly et al. (2010) concluded that organizations that reside those structural holes have a unique ability to reduce uncertainty and learn about sustainability, while Cronin et al. (2010) found out that companies with stronger ties to partners in upstream and downstream directions tend to achieve superior performance. Organizations that do not adapt their processes to become more sustainable may be selected out by the population (Carroll \& Buchholtz, 2015). In order to improve these systems, Malhotra et al. (2012) propose companies to use more decentralized systems to increase communication to strengthen ties with business partners. Moreover, the processes within the company should be improved by reducing waste in order to serve the Marketing 3.0 overall objective of making the world a better place (Iles, 2008; Cronin et al., 2010; Brindley \& Oxborrow, 2013; Liu \& Bai, 2014). 


\section{Dennis Warrink \\ The Marketing Mix in a Marketing 3.0 Context}

Additionally, companies increasingly make use of environmental management systems (EMS) with specific emphasis on getting these systems certified (Cronin et al., 2010). Cronin et al. (2010) further state that companies that use these formalized systems achieve higher performance compared to companies using informal systems since they provide tangible accountability for the processes and people involved. Also, it was indicated that firms with certified systems like ISO 14000 outperformed uncertified formal systems (Cronin et al., 2010). This is in line with further research that suggests that companies should increase transparency throughout important business processes and disclose all information regarding substantial risk associated with the product offering or its components in order to increase reliability of the company's business practices and promotions, resulting in trust among consumers (Iles, 2008; Ndubisi et al., 2013). Therefore, the emergence of Marketing 3.0 will conclude in the integration of sustainability throughout the supply chain and within the company, as well as the implementation of environmental management systems.

\subsection{People}

In regard to Marketing 3.0, companies need to teach their people sustainable behavior (Iles, 2008). This ensures that employees will more likely share the sustainable vision of the company, (Iles, 2008; Conelly et al., 2011). Malhotra etal. (2012) further state that, to enable efficient, sustainable business practices, all members of the organization must feel the desire and commitment to the business approach and accept their critical role in the implementation process of these business activities. Moreover, companies should treat customers, employees, and all stakeholders fairly with high ethical and integrity norms, taking into consideration economic interest, but also community's social benefits and employees' welfare (Luchs et al., 2010; Liu et al., 2012; Ndubisi et al., 2013). The effect on bad treatment towards employees can be seen by the example of Nike (Nisen, 2013). When Nike was accused of engaging in poor labor practices, especially with their use of child labor, the company's image was badly tarnished, and the number of sales decreased significantly (Nisen, 2013). This is why it is not surprising that research suggests that ethical, professional companies are likely to attract ethical job candidates, which tend to be more productive (Crane \& Matten, 2010; Ndubisi et al., 2013). Additionally, when companies implement ethical norms and behavior in the training of their employees' working roles, these are more likely to reflect ethical behavior (Crane \& Matten, 2010; Ndubisi et al., 2013). Hence, Marketing 3.0 introduces high ethical and integrity norms and results in an improved education of sustainable behavior among employees.

\subsection{Physical Evidence}

As research suggests, the decision to consider staying loyal to a certain product or service is greatly influenced by the emotions towards a brand (Gilmore \& Pine, 2007; Gupta \& Kim, 2010; Bell, 2011). Furthermore, establishing an environmental-friendly brand reputation is increa singly used to differentiate oneself from competitors, which is, according to Kotler (2010) crucial in order to stay relevant in business (Rahbar \& Wahid, 2011). This is why McDonalds changed its logo in 2009 from a red to a green background in order to appear more environmental-friendly and 'green' (MacPherson Lane, 2010). On the other hand, Meffert et al. (2010) state that creating a sustainable brand is only beneficial if it ensures a differentiation from direct competitors. Nevertheless, other research suggests that since consumers are increasingly requesting environmental-friendly products, a brand can build a competitive advantage by focusing on environmental and societal priorities (Liu et al., 2012; Susilo et al., 2015). Additionally, eco-branding can ease the promotion of sustainable products (Rahbar \& Wahid, 2011). A research by Rahbar \& Wahid (2011) even identified that the success of ecofriendly products heavily rely on the public image of the brand and that a positive public image leads to consumer loyalty. Nevertheless, it is stated that creating a sustainable brand should only be considered if sustainability is valued by the main target group (Meffert et al., 2010; Carroll \& Buchholtz, 2015). 


\section{Dennis Warrink \\ The Marketing Mix in a Marketing 3.0 Context}

On the contrary, Rahbar \& Wahid explained that a strong eco-brand can more easily educate consumers about the necessity to use environmental-friendly products and services, which is in line with Kotler et al.'s (2010) principle of making the world a better place. Nowadays, with Marketing 3.0, brand management is enhanced by building a character for the brand (Kotler et al., 2010; Meffert et al., 2010; Susilo et al., 2015). Kotler et al. (2010) states that character building for brands reflects the urgency for companies to develop an authentic DNA which acts as the core of their true differentiation (Kotler et al., 2010; Susilo et al., 2015). Furthermore, it is crucial that the true identity which is reflected by the DNA achieves authentic differentiation, since consumers view a brand and immediately judge whether it is fake or not (Kotler et al., 2010; Susilo et al., 2015). Overall, this implies that the brand obtains corporate social responsibility by embracing responsibility for their actions and encouraging positive actions and impacts on the environment in order to increase reliability and serve consumers desires of a better world (Crane \& Matten, 2010; Kotler et al., 2010). Therefore, modem Marketing 3.0 practices implies that companies build a character for the brand and accept their corporate social responsibilities.

\section{Ethical Issues Regarding Marketing 3.0}

Society becomes increasingly skeptical about the credibility, validity, and usefulness of sustainable marketing (Chen, 2010; Meffert et al., 2010; Delmas \& Burbano, 2011; Liu et al., 2012). Research reveals that there still is a number of companies that are promoting their products and services as socially and environmentally beneficial, even though they are not (Delmas \& Burbano, 2011; Walker \& Wan, 2012; Nyilasy et al., 2014). This tactic that mislead consumers regarding the environmental, social, and ethical benefits of a product or service or the environmental practices of a company in order to trick the consumer into buying their products and services is what research defines as greenwashing (Ghosh, 2010; Parguel, BenoîtMoreau, \& Larceneux, 2011; Walker \& Wan, 2012; de Vries, Terwel, Ellemers, \& Daamen, 2015; Humphrey \& Li, 2015). Hence, when engaging in greenwashing, companies falsely claim to solve societal anxieties by promoting to increase societal welfare, without a cting upon it in reality. Greenwashing can take many different forms. For instance, a company may communicate disinformation among society to shape or repair its reputation (de Vries et al., 2015). Also, it may publish an environmental promise without living up to it (Vos, 2009). However, corporate greenwashing is typically associated with a gap between rhetoric and reality (de Vries et al., 2015). The truth about Corporate Social Responsibility is therefore bent, overstated, or misrepresented in public communications (Vos, 2009; de Vries et al., 2015).

When the society suspects greenwashing, a range of damaging consequences like protest and boycott may occur, resulting in a financial loss for the company (de Vries, 2015). It leads to a further distrust amongst consumers towards companies, which is why a study conducted by de Vries et al. (2015) concluded that people easily suspect greenwashing when a company invests in environmental measures rather than economic measures since they assume that companies purely focus on firm-serving motives rather public-serving motives. This shows that companies increasingly face the problem that consumers do not believe in the company's environmental statements when promoting sustainability (Papadopoulos, Karagouni, Trigkas, \& Platogianni, 2010). Hence, the problem arises that also companies that actually pursue environmental business are harmed by the false claims of those companies who engage in greenwashing which leaves the potential benefits from engaging into sustainable and ethical marketing practices questionable, even for truly responsible companies (Parguel et al., 2011; Armstrong et al., 2014). Research further states that the absence of a central agency that can certify green accreditations of a company is one of the major factors that led to greenwashing, which allowed companies that did not act upon sustainable business behavior to call themselves sustainable, or environmental-friendly (Ghosh, 2010; Walker \& Wang, 2012). This can be further explained using the example of the UN Global Compact, a voluntary regulatory 


\section{Dennis Warrink \\ The Marketing Mix in a Marketing 3.0 Context}

program that seeks to improve environmental, human rights, and labor policies of participating firms (Berliner \& Prakash, 2015).

The Compact only requires members to prepare a letter of commitment, as well as annually communicate their progress, but the UN does not verify the claims made in any way (Crane \& Matten, 2010; Berliner \& Prakash, 2015). Since there are no mechanisms which make the adherence binding in any way, it is not clear whether the members will invest resources or make behavioral changes to fulfill their obligations (Delmas \& Cuerel-Burbano, 2011; Berliner \& Prakash, 2015). Therefore, society accuses companies of "bluewashing" $w$ hen it assumes that a company figuratively drapes itself in the UN flag in order to distract stakeholders from their poor environmental or human rights records, or to enhance their reputation (Berliner \& Prakash, 2015). Therefore, free-rider actions on the efforts of complying participants like these raises legitimate questions about such programs as tools to increase the, by consumers desired, sustainable and ethical behaviour amongst companies, and the effect of sustainable marketing practices, since consumers do not trust professional sustainable marketing practices anymore (Chen, 2010; Berliner \& Prakash, 2015). Furthermore, research increasingly suggest that governments should take a lead in setting up regulations, ultimately setting internationally-binding corporate social responsibility standards, in order to guarantee fair marketing practices, resulting into increasing consumers' confidence and increasing control over free-riders (Liu et al., 2012; Nyilasy et al., 2014; Berliner \& Prakash, 2015).

\section{Conclusion}

This paper provided a detailed overview of what Marketing 3.0 is, explained the various components in detail, and evaluated upon its influence of the widely known 7P marketing mix. Several knowledge discoveries were discovered throughout the development of this paper. While the introduction of Marketing 3.0 appears to have high influence on most of the Marketing Mix Ps, after the in-depth evaluation of current literature, it became explicit that current literature does not see a direct influence of Marketing 3.0 on all of the seven Ps. The effect of Marketing 3.0 on the 7Ps Marketing Mix can be seen in table 2. It represents the extent to which Marketing 3.0 influences the seven different Ps from the Marketing Mix. While a ' 0 ' indicates that current literature does not find any direct influence of Marketing 3.0 on the respective $P$, $a$ ' $x x^{\prime}$ indicates that current literature sees a high influence on the respective $P$.

Table 2: Results. The effect of Marketing 3.0 on the 7P Marketing Mix

\begin{tabular}{c|ccccccc}
\multicolumn{1}{c}{$\boldsymbol{P}$} & Product & $\begin{array}{c}\text { Plac } \\
\mathrm{e}\end{array}$ & Price & $\begin{array}{c}\text { Promotio } \\
n\end{array}$ & Process & People & $\begin{array}{c}\text { Physical } \\
\text { Evidence }\end{array}$ \\
\hline Effect & $\mathrm{xx}$ & $\mathrm{x}$ & $\mathrm{xx}$ & $\mathrm{xx}$ & $\mathrm{xx}$ & $\mathrm{xx}$ & $\mathrm{xx}$
\end{tabular}

As table 2 indicates, literature sees a high influence on the product, price, promotion, process, people, and physical evidence building blocks of the 7P marketing Mix from the emergence of Marketing 3.0. Additionally, literature does not see a high influence of Marketing 3.0 on place but presents potential indirect effects through technology improvements. The most relevant changes on the 7P Marketing Mix from the transition from Marketing 2.0 to Marketing 3.0 can be seen in table 3 .

With the introduction of Marketing 3.0, literature reveals that products need to fulfill individual, as well as societal needs, wants, and desires. This implies that products should not cause environmental harm, for both people and the planet. Co-creation is also a new way to more easily find out what consumers want and desire in their products. Furthermore, currently, sustainable products and services are more expensive than non-harmful ones. Research suggests that consumers increasingly are willing to pay premium prices for the type of products mentioned above. Nevertheless, higher prices regarding sustainable products resulting from higher costs of production will eventually be subsidized by governmental subsidies, as well as 


\section{Dennis Warrink \\ The Marketing Mix in a Marketing 3.0 Context}

the reduced amount of waste. Furthermore, the promotion changes into a vertical communication by creating, as well as engaging into communities. Also, environmental and societal value should be promoted in a believable way.

Table 3: Results. How the 7P Marketing Mix changed from Marketing 2.0 to Marketing 3.0

\begin{tabular}{|c|c|c|}
\hline & Marketing 2.0 & Marketing 3.0 \\
\hline Product & $\begin{array}{l}\text { - Products that fulfill individual } \\
\text { needs and wants }\end{array}$ & $\begin{array}{l}\text { - Products that fulfill individual and } \\
\text { societal needs, wants, and desires } \\
\text { - Co-creation }\end{array}$ \\
\hline Place & - Online sales & (· Further shift towards online sales) \\
\hline Price & - High price competition & $\begin{array}{l}\text { - Initial premium prices - eventually } \\
\text { compensated by cost savings from } \\
\text { waste reduction and government } \\
\text { subsidies } \\
\text { - Price advantage for reputable brands }\end{array}$ \\
\hline Promotion & $\begin{array}{l}\text { - Individual-value } \\
\text { - Mass communication }\end{array}$ & $\begin{array}{l}\text { - Horizontal communication } \\
\text { - Educate about sustainable behaviour }\end{array}$ \\
\hline Process & · Process Efficiency & $\begin{array}{l}\text { - Integrate sustainability throughout } \\
\text { the supply chain } \\
\text { - Integrate sustainability internally } \\
\text { (e.g. waste reduction) } \\
\text { - Implementation of EMS }\end{array}$ \\
\hline People & - Fair treatment of stakeholders & $\begin{array}{l}\text { - Share sustainable corporate vision } \\
\text { among employees } \\
\cdot \text { high ethical and integrity norms }\end{array}$ \\
\hline $\begin{array}{l}\text { Physical } \\
\text { Evidence }\end{array}$ & - Build a Brand & $\begin{array}{l}\text { - Build a character for the brand } \\
\text { - Accept Corporate Social Responsibility }\end{array}$ \\
\hline
\end{tabular}

Moreover, the Marketing 3.0 era changes the processes in form of integration of sustainability internally, as well as externally throughout the supply chain, as well as implementing Environmental Management Systems. This also entails that Marketing 3.0 changes the People building block by integrating high ethical and integrity norms amongst stakeholders, as well as sharing the sustainable vision amongst employees. Also, the implementation of Marketing 3.0 results in the establishment of a character for the brand, which now takes responsibility for harmful activities done in the past. Lastly, it can be stated that, even though the references on Marketing 3.0 do not identify a direct influence on the place building block, it is assumed that upcoming technological developments might result in a further shift towards online selling.

\section{Discussion}

The in-depth evaluation of Marketing 3.0's influence on the 7P Marketing Mix shows that six of the seven Ps of the Marketing Mix are influenced by Marketing 3.0. While literature does not clearly identify an influence on the place, the other six Ps were highly influenced by the emergence of Marketing 3.0 practices. Therefore, this paper provides academic, as well as practical implications, which will be explained in the following.

\section{Academic implications}

This paper provided the reader with an overview of what current literature describes at the main effects of Marketing 3.0 practices on the widely accepted 7P Marketing Mix, and how these influences change the way the traditional 7P Marketing Mix is viewed. Additional, theoretical support for the influence of Marketing 3.0 on six out of the seven Ps of the Marketing Mix was found and ascertained. The in-depth analysis of current literature provided a new way of regarding the 7P Marketing Mix with regards to societal and environmental value. Furthermore, an analysis was provided concerning the issues that arise with the emergence of Marketing 3.0, which can be seen as a foundation for further research in this area to increase the effectiveness and efficiency of Marketing 3.0 practices in the future. 


\section{Dennis Warrink \\ The Marketing Mix in a Marketing 3.0 Context}

\section{Practical implications}

This research has some important practical implications as well. It provides substantial marketing research insights for Marketing 3.0 on its way to influence the way companies should organize their business practices. The results show what to focus on when implementing Marketing 3.0 practices into business operations. For example, a company which aims to incorporate Marketing 3.0 practices can find ways on what to consider when producing suitable products that satisfy the consumers' minds, hearts, and spirits, while also showing the company how to promote these efficiently, how to treat people, and what needs to be considered when building a character for the brand.

Nevertheless, the extent to which a company takes the outcomes into consideration should depend upon past business practices, the industry, and the extent to which a company can find unfulfilled societal desires among their main consumers. Also, it has to be stated that the implementation of Marketing 3.0 practices is considered to be more necessary in some industries than in others. Literature reveals that, for instance, food industries are highly advised to incorporate sustainable marketing practices while the degree to which these practices should be implemented are less crucial for industries like software industries (Meffert et al., 2010; Walker \& Wan, 2012).

\subsection{Limitations}

While this literature review presented some valuable new insights, there are some limitations that should be taken into account. Firstly, even though the findings of this literature review does provide a comprehensive overview on the influence of Marketing 3.0 on the 7P Marketing Mix, it takes a rather general approach and does not provide recommendations for certain industries. Moreover, this literature review was conducted within a predetermined time frame of eight weeks from the beginning to the final submission of the paper. This limits the time to search, read, and evaluate information, and to conduct a comprehensive, academically valuable research paper. Additionally, since the University of Twente does not have access to some of the online literature, there is a chance that not all relevant literature was not taken into consideration. Furthermore, since this literature review solely evaluates upon existing state-of-art literature, it does not provide any new, never-mentioned-before information, which could have been obtained by an empirical research. Next to that, it has to be stated that the topic of Marketing 3.0 is a comparatively new concept, and therefore, the number of empirical research is limited, which influences the reliability of the curre nt, more theoretical findings.

\subsection{Further Research}

This research presents a comprehensive foundation on the effect Marketing 3.0 has on the marketing strategy of a company. Nevertheless, since this research was solely conducted upon other researches, further research on the basis of this review can empirically test the prin ciples discussed in this paper and can verify, falsify or add findings to this paper.

Furthermore, future research can identify not only what companies have to adapt in their current business when they want to adopt a strategy according to Marketing 3.0, but rather establish how companies can do this most efficiently while saving costs of implementation in order to further motivate companies to engage in more sustainable environmental valuecreating and ethical business a ctivities. Additionally, this evaluation can be done more precisely for specific industries, especially those where the implementation of Marketing 3.0 practices seems most valuable, for instance, the food industry (Meffert et al., 2010; Walker \&Wan, 2012).

Lastly, it is recommended that future research focuses on identifying ways to reduce the amount of greenwashing and further unethical behavior towards Marketing 3.0 activities, in order to minimize free riders and increase the number of resources invested in the Marketing 3.0 aim of making the world a better place. 


\author{
Dennis Warrink \\ The Marketing Mix in a Marketing 3.0 Context
}

\title{
Acknowledgements
}

The author is grateful to Dr. E. Constantinides, P. Bliek, and S. Mehrtens for their support in the diverse ways in which they contributed to letting this paper flourish. Special thanks to the Editors of the Journal for the many valuable comments on the previous version of the paper which has improved its quality and content to the present state.

\section{References}

- Achrol, R. S., \& Kotler, P. (2012). Frontiers of the marketing paradigm in the third millennium. Journal of the Academy of Marketing Science, 40(1), 35-52. Crossref

- Adcock, D., Halborg, A., Ross, C., \& Financial Times Limited. (2001). Marketing: Principles and practice (4th ed.). Harlow: Financial Times/Prentice Hall.

- Ansar, N. (2013). Impact of Green Marketing on Consumer Purchase Intention. Mediterranean Journal of Social Science, 4(11), 650-655. Crossref

- Armstrong, G., Adam, S., Denize, S. M., \& Kotler, P. (2014). Principles of marketing (11th ed.). Pearson.

- Bell, H. A. (2011). A Contemporary Framework for Emotions in Consumer DecisionMaking: Moving Beyond Traditional Models. International Journal of Business and Social Science, 2(17), 12-16.

- Berliner, D., \& Prakash, A. (2015). "Bluewashing" the Firm? Voluntary Regulations, Program Design, and Member Compliance with the United Nations Global Compact. Policy Studies Journal, 43(1), 115-138. Crossref

- Berthon, P. R., Pitt, L. F., Plangger, K., \& Shapiro, D. (2012). Marketing meets Web 2.0, social media, and creative consumers: Implications for international marketing strategy.

- Bitner, M. J. and Booms, H. (1981). Marketing Strategies and Organization: Structure for Service Firms. In Donnelly, J. H. and George, W. R. (Eds). Marketing of Services, Conference Proceedings. Chicago, IL. American Marketing Association. p. 47- 52.

- Boyd, D., \& Ellison, N. B. (2007). Social Network Sites: Definition History and Scholarship. Journal of Computer-mediated Communication. Crossref

- Bridges, C. M., \& Wilhelm, W. B. (2008). Going Beyond Green: The "Why and How" of Integrating Sustainability Into the Marketing Curriculum. Journal of Marketing Education, 30(1), 33-46. Crossref

- Brindley, C., \& Oxborrow, L. (2014). Aligning the sustainable supply chain to green marketing needs: A case study. Industrial Marketing Management, 43(2014), 45-55. Crossref

- Carroll, A. B., \& Buchholtz, A. K. (2015). Business \& society: Ethics, sustainability, and stakeholder management (9th ed.). Australia: South-Western, Cengage Learning.

- Chartered Institute of Marketing (CIM). (2009). Marketing and the 7PS: A Brief Summary of Marketing and How It Works. Knowledge Hub

- Chatterjee, P. (2011). Drivers of new product recommending and referral behaviour on social network sites. International Journal of Advertising, 30(1), 77-101. Crossref

- Chen, J. Z. (2009). Material flow and circular economy. Systems Research and Behavioural Science. doi:10.1002/sres.968. Crossref

- Chen, K. J., Chen, M. L., Liu, C. M., \& Huang, C. J. (2011). Integrated Marketing Communication, Collaborative Marketing, and Global Brand Building in Taiwan. International Journal of Organizational Innovation, 7(4), 99-107.

- Chen, Y. (2010). The Drivers of Green Brand Equity: Green Brand Image, Green Satisfaction, and Green Trust. Journal of Business Ethics, 93, 307-319. Crossref

- Connelly, B. L., Jr, D. J., \& Slater, S. F. (2011). Toward a "theoretical toolbox" for sustainability research in marketing. Journal of the Academy of Marketing Science, 39, 86-100. Crossref

- Covey, S. R. (2005). The 8th habit: From effectiveness to greatness. New York: Free Press. 


\section{Dennis Warrink \\ The Marketing Mix in a Marketing 3.0 Context}

- Crane, A., \& Matten, D. (2010). Business ethics: Managing corporate citizenship and sustainability in the age of globalization (3rd ed.). Oxford: Oxford University Press.

- Cronin, J. J., Smith, J. S., Gleim, M. R., Ramirez, E., \& Martinez, J. D. (2011). Green marketing strategies: an examination of stakeholders and the opportunities they present. Journal of the Academy of Marketing Science, 39, 158-174. Crossref

- Dann, S. (2009). Redefining social marketing with contemporary commercial marketing definitions. Journal of Business Research, 63(2), 147-153. Crossref

- De Vries, G., Terwel, B. W., Ellemers, N., \& Dancker, D. D. (2015). Sustainability or Profitability? How Communicated Motives for Environmental Policy Affect Public Perceptions of Corporate Greenwashing. Corporate Social Responsibility and Environmental Management, 22, 142-154. Crossref

- Delmas, M. A., \& Burbano, V. C. (2011). The Drivers of Greenwashing. University of California, Berkeley, 54(1), 64-87. Crossref

- Dishman, L. (2014, September 4). Inside H\&M's Quest for Sustainability in Fast Fashion. Forbes.

- Drucker, P. F. (2006). Classic Drucker: Essential wisdom of Peter Drucker from the pages of Harvard Business Review. Boston: Harvard Business Review Book.

- Erragcha, N., \& Romdhane, R. (2014). New Faces of Marketing in the era of the Web: From Marketing 1.0 to Marketing 3.0. Journal of Research in Marketing, 2(2), 137-142.

- Florida, R. L. (2005). The flight of the creative class: The new global competition for talent. New York: Harper Business.

- Fournier, S., \& Lee, L. (2009). Getting Brand Communities Right. Harvard Business Review, 107-111.

- French, J., \& Blair-Stevens, C. (2006). From Snake Oil Salesmen to Trusted Policy Advisors: The Development of a Strategic Approach to the Application of Social Marketing in England. Social Marketing Quarterly. Crossref

- Fuchs, C., Hofkirchner, W., Schafranek, M., Raffl, C., Sandoval, M., \& Bichler, R. M. (2010). Theoretical Foundations of the Web: Cognition, Communication, and CoOperation. Towards an Understanding of Web 1.0, 2.0, 3.0. Future Internet.

- Ghosh, M. (2010). Green Marketing - A changing concept in changing time. BVIMR Management Edge, 4(1), 82-92.

- Gilmore, J. H., \& Pine, B. J. (2007). Authenticity: What consumers really want. Boston, MA: Harvard Business School Press.

- Goetzinger, L., Lee, Y. J., \& Widdows, R. (2007). Value-driven consumer e-health information search behavior. International Journal of Pharmaceutical and Healthcare Marketing, 1(2), 128-142. Crossref

- Gubbi, J., Buyya, R., Marusic, S., \& Palaniswami, M. (2013). Internet of Things (IoT): A vision, architectural elements, and future directions. Future Generation Computer Systems, 29, 1645 - 1660. Crossref

- Gupta, S., \& Kim, H. (2010). Value-driven Internet shopping: The mental accounting theory perspective. Psychology \& Marketing, 27(1), 13-35. Crossref

- Handy, C. B. (1998). The hungry spirit: Beyond capitalism: a quest for purpose in the modern world. New York: Broadway Books.

- Held, D., McGrew, A., \& Goldblatt, D. (1999). Global transformations: Politics, economics and culture. Stanford, CA: Stanford University Press.

- Hettler, U. (2010). Social Media Marketing: Marketing mit Blogs, sozialen Netzwerken und weiteren Anwendungen des Web 2.0. München: Oldenbourg.

- Iles, A. (2008). Shifting to green chemistry: the need for innovations in sustainability marketing. Business Strategy and the Environment, 17, 524-535. Crossref

- Humphrey, J., \& Li, Y. (2015). Commitment to change or greenwashing? Mutual fund's response to environmental, social, and governance initiatives. Social Science Research Network, 1-26.

- Kaplan, A. M., \& Haenlein, M. (2010). Users of the world, unite! The challenges and opportunities of Social Media. Business Horizons. Crossref 


\section{Dennis Warrink \\ The Marketing Mix in a Marketing 3.0 Context}

- Katona, Z., Zubcsek, P. P., \& Sarvary, M. (2011). Network Effects and Personal Influences: Diffusion of an Online Social Network. Journal of Marketing Research, 48(3), 425-443. Crossref

- Kietzmann, J. H., Hermkens, K., McCarthy, I. P., \& Silvestre, B. S. (2011). Social media? Get serious! Understanding the functional building blocks of social media. Business Horizons, 54, 241-251. Crossref

- Kimmel, A. J. (2015). Connecting with consumers via live buzz marketing: public perceptions and the role of ethical ideology. Business Ethics: A European Review, 24(2), 205-220. Crossref

- Klepic, J. (2014, September 16). How Cultural Marketing is different from Consumer Insights. Huffington Post.

- Kotler, P. (2011). Reinventing Marketing to Manage the Environmental Imperative. Journal of Marketing, 75, 132-135. Crossref

- Kotler, P., Kartajaya, H., Setiawan, I., \& Wiley InterScience (Online service). (2010). Marketing 3.0: From products to customers to the human spirit. Hoboken, NJ: Wiley.

- Kotler, P., \& Lee, N. (2008). Social marketing: Influencing behaviours for good. Los Angeles: Sage Publications.

- Lee, G., \& Kwak, Y. H. (2012). An Open Government Maturity Model for social mediabased public engagement. Government Information Quarterly, 29(4), 492-503. Crossref

- Lee, N., Kotler, P., \& Kotler, P. (2011). Social marketing: Influencing behaviors for good (4th ed.). Thousand Oaks, CA: SAGE Publications.

- Leonidou, L. C., Leonidou, C. N., Fotiadis, T. A., \& Zeriti, A. (2013). Resources and capabilities as drivers of hotel environmental marketing strategy: Implications for competitive advantage and performance. Tourism Management, 35, 94-110. Crossref

- Liu, S., Kasturiratne, D., \& Moizer, J. (2012). A hub-and-spoke model for multidimensional integration of green marketing and sustainable supply chain management. Industrial Marketing Management, 41, 581-588. Crossref

- Liu, Y., \& Bai, Y. (2014). An exploration of firms' awa reness and behaviour of developing circular economy: An empirical research in China. Resources, Conservation and Recycling, 87, 145-152. Crossref

- Luchs, M. G., Naylor, R. W., Irwin, J. R., \& Raghunathan, R. (2010). The Sustainability Liability: Potential Negative Effects of Ethicality on Product Preference. Journal of Marketing, 74, 18-31. Crossref

- Malhotra, N. K., Lee, O. F., \& Uslay, C. (2012). Mind the gap: The mediating role of mindful marketing between market and quality orientations, their interaction, and consequences. International Journal of Quality \& Reliability Management, 29(6), 607-626. Crossref

- MacPherson Lane, M. (2010, March 18). McDonald's Logo to go "Green" in Europe. Huffington Post.

- Mäler, \& K.-G. (2013). Environmental Economics: A Theoretical Inquiry (7th ed.). Hoboken: Taylor and Francis.

- McCarthy, E. J. (1964). Basic marketing: A managerial approach. Homewood, IL: R.D. Irwin.

- McDonagh, P., \& Prothero, A. (2014). Sustainability marketing research: past, present and future. Journal of Marketing Management, 30, 1186-1219. Crossref

- Meffert, H., Rauch, C., \& Lepp, H. L. (2010). Sustainable Branding - mehr als ein neues Schlagwort?! Marketing Review St. Gallen, 5, 28-35.

- Ndubisi, N. O., Nataraajan, R., \& Lai, R. (2014). Customer perception and response to ethical norms in legal services marketing. Journal of Business Research, 67, 369-377. Crossref

- Nyilasy, G., Gangadharbatla, H., \& Paladino, A. (2014). Perceived Greenwashing: The Interactive Effects of Green Advertising and Corporate Environmental Performance on Consumer Reactions. Journal of Business Ethics, 125, 693-707. Crossref 


\section{Dennis Warrink \\ The Marketing Mix in a Marketing 3.0 Context}

- Papadopoulos, I., Karagouni, G., Trigkas, M., \& Platogianni, E. (2010). Green marketing: The case of Greece in certified and sustainably managed timber products. Euromed Journal of Business, 5(2), 1-23. Crossref

- Parguel, B., Benoît-Moreau, F., \& Larceneux, F. (2011). How Sustainability Ratings Might Deter 'Greenwashing': A Closer Look at Ethical Corporate Communication. Journal of Business Ethics, 102, 15-28. Crossref

- Park, H., \& Kim, Y. K. (2014). The role of social network websites in the consumer-brand relationship. Journal of Retailing and Consumer Services, 21,460-467. Crossref

- Palmer, A. (2012). Introduction to marketing: Theory and practice (3rd ed.). Oxford: Oxford University Press.

- Pink, D. H. (2005). A whole new mind: Moving from the information age to the conceptual age. New York: Riverhead Books.

- Rahbar, \& Wahid. (2011). Investigation of green marketing tools' effect on consumers' purchase behaviour. Business Strategy Series, 12(2), 73-83. Crossref

- Rawat, S. R., Bhatia, K., Hegde, M., Bhat, N., \& Tewari, S. (2015). The Importance of Ethical Marketing Practices. Journal of Business Management and Economics, 3(2), $23-30$.

- Reisch, L. A., \& Thøgersen, J. (2015). Handbook of Research on Sustainable Consumption. Edward Elgar Publishing. Crossref

- Rettie, R., Burchell, K., \& Riley, D. (2012). Normalising green behaviours: A new approach to sustainability marketing. Journal of Marketing Management, 28(3), 420-444. Crossref

- Ries, A., \& Trout, J. (1988). Positioning: The battle for your mind (2nd ed.). Fullerton, CA: TDM/McGraw-Hill.

- Sharma, A., \& Iyer, G. R. (2012). Resource-constrained product development: Implications for green marketing and green supply chains. Industrial Marketing Management, 41, 599-608. Crossref

- Stiglitz, J. E. (2002). Globalization and its discontents. New York: W.W. Norton.

- Susilo, W. H., Yulius, Y., \& Suryati, L. (2015). Role of Communitization Marketing 3.0 on Purchasing in Higher Education of Postgraduate Institutions in Jakarta. Mediterranean Journal of Social Sciences, 6(2), 125-132.

- Sweeney, M. (2014, November 26). YouTubers ads for Oreo banned for not making clear purpose of videos. The Guardian.

- Thomas, J. M., \& Callan, S. J. (2007). Environmental economics: Applications, policy, and theory (4th ed.). Mason, $\mathrm{OH}$ : Thomson/South-Western.

- Thring, O. (2013, January 29). Is McDonald's actually getting healthier or does it just have good PR? Business Insider.

- Trefis Team. (2011, December 12). McDonald's, Chipotle, Starbucks try getting greener. Forbes

- Tukker, A. (2013). Product services for a resource-efficient and circular economy - a review. Journal of Cleaner Production, 97, 76-91. Crossref

- Vos, J. (2009). Actions speak louder than words: Greenwashing in corporate America. Notre Dame Journal of Law, Ethics \& Public Policy 23: 673-697.

- Walker, K., \& Wan, F. (2012). The Harm of Symbolic Actions and Green-Washing: Corporate Actions and Communications on Environmental Performance and Their Financial Implications. Journal of Business Ethics, 109, 227-242. Crossref

- Williams, D. K. (2013, June 18). Collaborative Marketing is the next big thing. Forbes.

- Zohar, D., \& Marshall, I. N. (1990). The quantum self: Human nature and consciousness defined by the new physics. New York: Morrow.

Online References:

- American Marketing Institute. (2015). Definition of Marketing - first stated 2008, approved 2013. Retrieved May 18, 2015, from https://w w w.ama.org/aboutama/pages/definition-of-marketing.aspx 


\section{Dennis Warrink}

The Marketing Mix in a Marketing 3.0 Context

- Google Trends. (2015). The Interest on the topic of Marketing 3.0 over time (2006-2015). Retrieved May 15, 2015, from

https://www.google.com/trends/explore\#q=marketing $\% 203.0$

- Nielsen. (2012, August 3). Newswire | Buzz in the Blogosphere: Millions More Bloggers and Blog Readers | Nielsen. Retrieved from

http://www.nielsen.com/us/en/insights/news/2012/buzz-in-the-blogosphere-millionsmore-bloggers-and-blog-readers.html

- Wikipedia, the free encyclopaedia. (2015). Wikipedia: Size of Wikipedia - Wikipedia, the free encyclopaedia. Retrieved May 19, 2015, from

http://en.wikipedia.org/wiki/Wikipedia:Size_of_Wikipedia

\section{Appendix}
Interest over time
News headlines

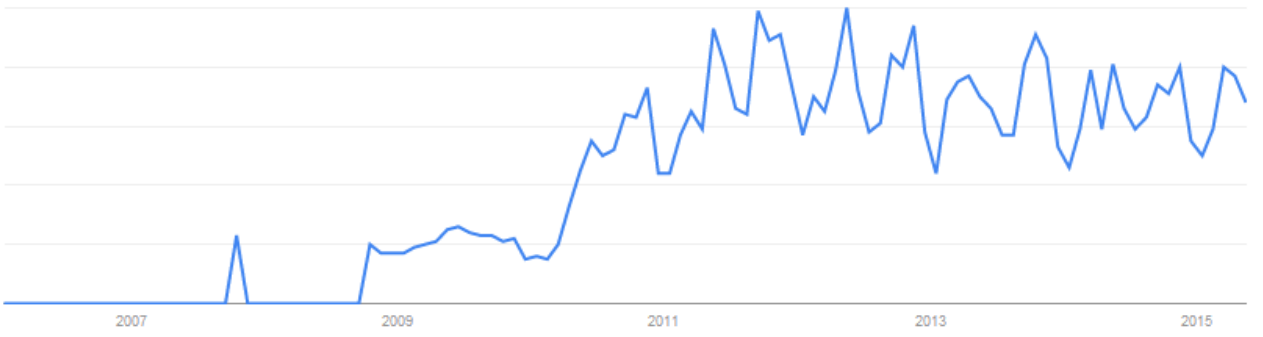

$\langle/\rangle$

Figure 1: The interest on the topic of Marketing 3.0 over time (Google, 2015)

\section{Table 1}

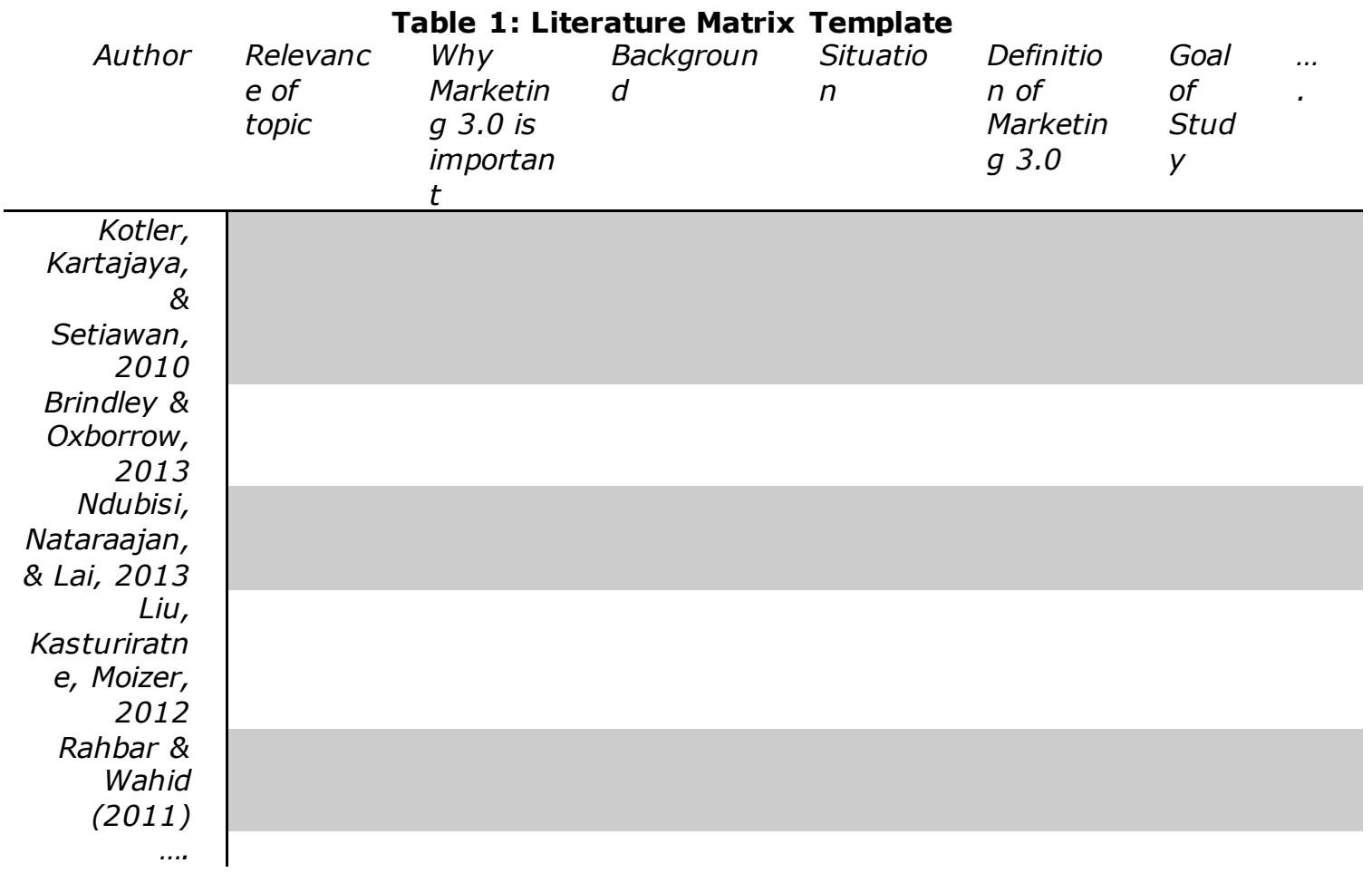




\section{Figure 2}

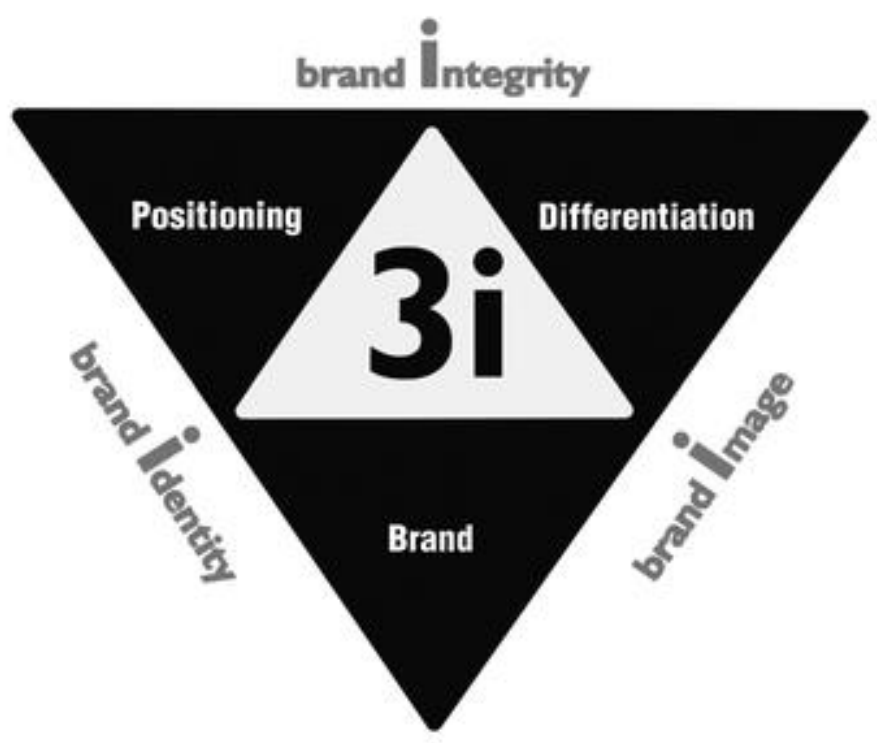

Figure 2. The 3i Model, Reprinted from Marketing 3.0: From Products to Customers to Human Spirit (p. 3), by P. Kotler, H. Kartajaya, I. Setiawan, 2010: New Jersey, Hoboken. Copyright [2010] by the Philip Kotler, Hermawan Kartajaya, and Iwan Setiawan.

\section{Figure 3}

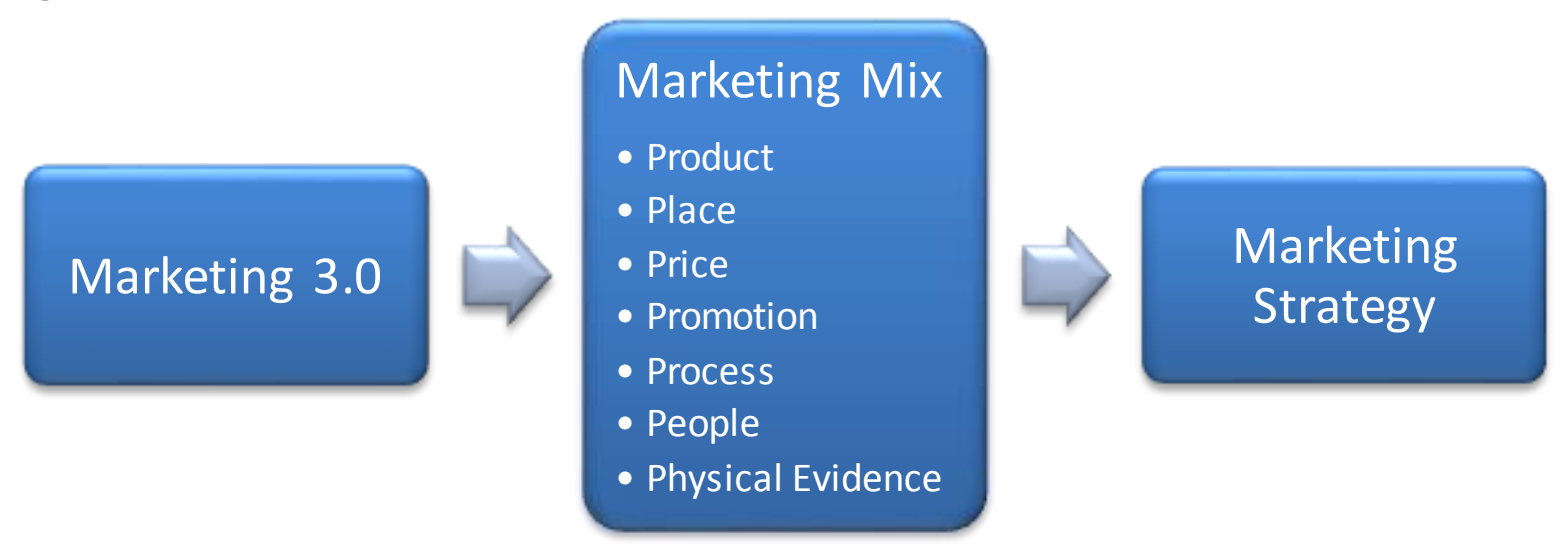

Figure 3. Theoretical Framework: Marketing 3.0's potential influence on the 7P Marketing Mix 